\title{
Enthalpy and Specific Heat of Four Corrosion-Resistant Alloys at High Temperatures
}

\author{
Thomas B. Douglas and James L. Dever
}

\begin{abstract}
Specific heats that are believed to be accurate in general to within \pm 2 percent are reported tor four alloys: from $0^{\circ}$ to $900^{\circ} \mathrm{C}$ for $80 \mathrm{Ni}-20 \mathrm{Cr}$ and two stainless steels (type 347 , containing 18 percent of chromium, 11 percent of nickel, and 1 percent of niobium, and type 446 , containing 26 percent of chromium); and from $0^{\circ}$ to $300^{\circ} \mathrm{C}$ for Monel, containing 67 percent of nickel and 30 percent of copper. These values were calculated from enthalpies measured with a drop method and a precision Bunsen ice calorimeter. The relatively small amounts of heat lost by the alloys as they dropped from the furnace to the calorimeter were estimated and corrections were applied therefor. Discontinuities in specific heat were found only in the case of $80 \mathrm{Ni}-20 \mathrm{Cr}$ and the stainless steel type 446.
\end{abstract}

\section{Introduction}

During the past several years the specific heats of a large number of substances have been measured precisely between $0^{\circ}$ and $900^{\circ} \mathrm{C}$ at the National Bureau of Standards. In each case this involved measurements not only with the sample in a suitable container, but also with the empty container as well, in order to determine by difference the net effect of the sample alone. Each such container consisted of a thin-walled cylinder, $5 / 8$ in. in diameter, and was usually composed of one of four alloys: $80 \mathrm{Ni}-20 \mathrm{Cr}$, Monel, or stainless steel type 347 or 446 (Am. Iron \& Steel Inst. designation). These alloys have numerous uses because of their relatively high resistance to corrosion, but apparently few measurements of their specific heats at elevated temperatures have been reported.

In the experiments recorded in this paper, the specimens used were themselves empty containers of the type previously used for measurements on other materials, such as aluminum oxide. The accuracy is somewhat less than in the earlier work because there is no cancellation of the small heat losses resulting from subtraction of blank measurements with an empty container. In addition, the following two factors should be pointed out, which, in the present case, somewhat limit the accuracy with which such measurements on only a few specimens can be applied to all specimens of the same general alloy: (a) As these four alloys are relatively hard materials, the previous thermal and mechanical history of a given specimen may sometimes cause it to exist in some less stable state that possesses a somewhat different specific heat; (b) a single name is often applied to a group of alloys whose chemical compositions, although nearly the same, are not exactly so. Fortunately, the specific heats of the main constituent elements of these four alloys are not very different, thus tending to reduce any error from this source. In fact, only in the temperature region of a transition or where two phases coexist does it seem likely that these factors may lead to serious lack of reproducibility in specific heat.

\section{Experimental Procedure}

Very detailed descriptions and evaluations of the method and apparatus used for measuring the enthalpy are contained in two papers [1] ${ }^{1}$ and in a later paper [2], describing the modified form of apparatus used in the present work. In brief, the method consisted of heating the specimen in a furnace to each of several known temperatures and then dropping it into an ice calorimeter, by means of which the heat evolved in cooling the specimen to $0^{\circ} \mathrm{C}$ was measured. The specimen container (which was the actual specimen in the present work) was suspended in the furnace and calorimeter by a No. 32 wire of $80 \mathrm{Ni}-20 \mathrm{Cr}$. This container and wire were connected by a short platinumrhodium wire to which were attached two thin platinum disks that also entered the calorimeter. These disks greatly reduced upward loss of heat from the specimen. The helium inside tbe container, as well as a gold gasket in the case of $80 \mathrm{Ni}-20 \mathrm{Cr}$, also entered the calorimeter during the drop. Helium was continuously passed through the cores of the calorimeter and the furnace, in order to reduce oxidation of the sample and to hasten the attainment of thermal equilibrium. The temperature of the furnace was kept constant during each run to within $\pm 0.01 \mathrm{deg}$ for a sufficient length of time to allow the sample to attain the same temperature. The temperatures were measured up to $600^{\circ} \mathrm{C}$ with a platinum resistance thermometer and above $600^{\circ} \mathrm{C}$ with a platinum-platinum-rhodium thermocouple, both of which had been calibrated in terms of the International Temperature Scale of 1948. The calibration factor of the ice calorimeter, which was based on numerous earlier electrical determinations at the Bureau, was taken to be 64.646 calories per gram of mercury ( $1 \mathrm{cal}=4.1840$ absolute joules).

Because, as mentioned above, these alloys were not themselves in containers, it was necessary to estimate and apply two small but appreciable corrections to each heat measurement, namely, for

Figures in brackets indicate the literature references at the end of this paper. 
TABLE 1. Chemical compositions of the alloys

\begin{tabular}{|c|c|c|c|c|c|}
\hline \multirow{2}{*}{ Element } & \multirow{2}{*}{$80 \mathrm{Ni}-20 \mathrm{Cr}$} & \multicolumn{2}{|c|}{ Monel sample- } & \multicolumn{2}{|c|}{ Stainless steel- } \\
\hline & & 1 & 2 & 347 & 446 \\
\hline $\begin{array}{l}\text { Iron } \\
\text { Nickel } \\
\text { Chromium } \\
\text { Copper. } \\
\text { Manganese } \\
\text { Niobium (columbi- } \\
\text { um) } \\
\text { Silicon } \\
\text { Carbon } \\
\text { Sulfur } \\
\text { Phosphorus } \\
\text { Totalaccount- } \\
\text { ed for, \% }\end{array}$ & $\begin{array}{l}\% \\
0.45 \\
77.4 \\
19.5 \\
0.59 \\
\\
1.4 \\
0.04 \\
\end{array}$ & $\begin{array}{r}0.07 \\
.18 \\
99.4\end{array}$ & \begin{tabular}{r}
0.07 \\
.12 \\
\hdashline \\
99.7
\end{tabular} & $\begin{array}{r}\% \\
(\mathrm{a}) \\
11.1 \\
18.3 \\
1.30 \\
0.86 \\
.52 \\
.08 \\
\\
\end{array}$ & $\begin{array}{c}\% \\
(\mathrm{a}) \\
0.32 \\
25.58 \\
0.42\end{array}$ \\
\hline
\end{tabular}

s Not determined.

(a) the heat lost during the drop through the region between the furnace and the calorimeter, and (b) the heat delivered by the irrelevant parts of the system dropping into the calorimeter. The value used for the first correction was the mean of the calculated and observed values previously discussed [2].

The four alloys used were of commercial grade. In those cases where measurements were made with several specimens of the same alloy, the specimens were taken from adjacent parts of the same sample of rod or tubing. Except in the case of the Monel, which was stated to be in cold-drawn condition, they were heated to above $1,000^{\circ} \mathrm{C}$ and allowed to cool in air before beginning measurements of their enthalpy. Each specimen had a mass between 8 and $17 \mathrm{~g}$, and carried with it into the calorimeter 0.3 to $0.5 \mathrm{~g}$ of platinum metals. The 80 $\mathrm{Ni}-20 \mathrm{Cr}$ was accompanied also by 0.3 to $0.6 \mathrm{~g}$ of gold, and the other three alloys, by about $0.1 \mathrm{~g}$ of $80 \mathrm{Ni}-20 \mathrm{Cr}$. In the course of the measurements, all the alloys except the Monel acquired oxide coatings in varying amounts up to a few hundredths of a gram. The thermal contributions of the small amounts of these irrelevant materials, which constitute correction (b) of the preceding paragraph, were estimated from specific-heat data in the literature and were corrected for by deduction from the results found.

A separate specimen of each alloy, taken from the same sample as those used in the thermal measurements, was analyzed chemically. The resulting compositions are given in table 1, and fall within the ranges of nominal composition for alloys of these designations [3].

\section{Results}

The enthalpy measurements were on two specimens of $80 \mathrm{Ni}-20 \mathrm{Cr}$, on one each of Monel and stainless steel 446, and on six of stainless steel 347 (of which two were not run above $450^{\circ} \mathrm{C}$ ). Several duplicate measurements were made on each speci-
TABLE 2. Mean corrected enthalpy

\begin{tabular}{|c|c|c|c|c|c|c|c|}
\hline \multirow{3}{*}{$\begin{array}{l}\text { Tem- } \\
\text { pera- } \\
\text { ture }\end{array}$} & \multicolumn{5}{|c|}{ Corrected enthalpy, $H_{t}-H_{0}$, cal g-1 } & \multirow{2}{*}{\multicolumn{2}{|c|}{$\begin{array}{l}\text { Major corrections } \\
\text { for stainless steel } \\
446 \text {, cal g-1 }\end{array}$}} \\
\hline & \multicolumn{2}{|c|}{$\begin{array}{l}80 \mathrm{Ni}-20 \mathrm{Cr} \text { speci- } \\
\text { men- }\end{array}$} & \multirow{2}{*}{ Monel } & \multicolumn{2}{|c|}{ Stainless steel一 } & & \\
\hline & 1 & 2 & & 347 & 446 & $\begin{array}{l}\mathrm{Pt}, 80 \\
\mathrm{Ni}-20 \mathrm{Cr}\end{array}$ & $\begin{array}{l}\text { Heat } \\
\text { lost in } \\
\text { drop }\end{array}$ \\
\hline${ }^{\circ} \mathrm{C}$ & & & & & & & \\
\hline 25.0 & - & & 2.53 & & $\ldots$ & $\ldots$ & -... \\
\hline $\begin{array}{l}50.0 \\
75.0\end{array}$ & - & 5. 23 & $\begin{array}{l}5.09 \\
7.72\end{array}$ & 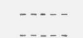 & $-\cdots$ & -..- & $-\cdots$ \\
\hline 94.0 & 10.11 & 9.98 & & & -.... & $\cdots$ & \\
\hline 100.0 & -.... & -...- & 10.33 & 11. 39 & 11. 31 & -0.17 & +0.01 \\
\hline 150.0 & $21-76$ & 16. 26 & 15. 65 & $\ldots$ & 17.38 & -.25 & +.04 \\
\hline 200.0 & 21.60 & & 21.10 & 23.49 & 23.72 & -.34 & +07 \\
\hline 250.0 & & 27.93 & 26. 63 & -... & 30.28 & -.42 & +.10 \\
\hline 298.3 & 34.12 & 33. 71 & ..... & - . - & $\ldots$ & ...... & ..... \\
\hline 300.0 & -...- & -.. & 32.24 & 36.07 & 37.17 & -.51 & +.14 \\
\hline 350.0 & $46 \quad 13$ & 45.54 & -...- & - - - & 44.32 & -.59 & +.19 \\
\hline $\begin{array}{l}394.6 \\
400.0\end{array}$ & 46.13 & 45. & ...... & 49.13 & 51.75 & -.68 & +25 \\
\hline 497.8 & 59.55 & 58.65 & ... & -... & - . & $\ldots$ & -20 \\
\hline 500.0 & & & - & 62.61 & 67.31 & -.84 & +.40 \\
\hline 597.6 & 72.93 & 71.91 & $\ldots$ & & & & \\
\hline $\begin{array}{l}600.0 \\
699.5\end{array}$ & 87.92 & 86.45 & 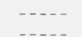 & $\begin{array}{l}76.42 \\
90.65\end{array}$ & 87.67 & -1.01 & +.61 \\
\hline 701.2 & ..... & -..... & - & - - & 106.19 & -1.18 & +.88 \\
\hline $\begin{array}{l}796.5 \\
860.0\end{array}$ & 102.49 & $\begin{array}{l}100.84 \\
110.40\end{array}$ & $\cdots$ & 104.98 & 121.95 & -1.34 & +1.22 \\
\hline 896.0 & 118.00 & 115.88 & $\ldots$ & 119.87 & 138.11 & -1.51 & +1.66 \\
\hline
\end{tabular}

men at each furnace temperature, the average deviation from the mean being 0.03 cal $\mathrm{g}^{-1}$, or about 0.05 percent of the total heat measured. The different specimens of stainless steel 347 showed small differences that were systematic with temperature and averaged 0.25 percent of the measured heat. The corrected net heat values for the two specimens of $80 \mathrm{Ni}-20 \mathrm{Cr}$, however, differed by approximately 1.5 percent at each furnace temperature. As this difference is many times the precision of the measurements, it is attributed to differences in the two specimens.

Relative to that at $0^{\circ} \mathrm{C}$, the mean observed enthalpy at each furnace temperature, corrected as described above but unsmoothed, is given for each alloy in table 2. The mean values for the two specimens of $80 \mathrm{Ni}-20 \mathrm{Cr}$ are listed separately because of their considerable differences. In the last two columns are given (in calories per gram of alloy) the major corrections that were made to the values for stainless steel 446 . The corresponding corrections for the other three alloys were very similar in magnitude.

The following equations, derived from the values of table 2, represent the relationship between enthalpy (in cal $\mathrm{g}^{-1}$ ) and temperature (in $\mathrm{deg} \mathrm{C}$ ). The average departure of the observed values from these equations is about $0.02 \mathrm{cal} \mathrm{g}^{-1}$ (less than 0.1 percent). The equations for $80 \mathrm{Ni}-20 \mathrm{Cr}$ were derived from the mean values observed with the two specimens. 
$80 \mathrm{Ni}-20 \mathrm{Cr}$ :

$$
\begin{aligned}
& H_{t}-H_{0}=0.1033 t+3.8\left(10^{-5}\right) t^{2} \quad\left(0^{\circ} \text { to } 150^{\circ} \mathrm{C}\right) . \\
& H_{t}-H_{0}=-0.33+0.1079 t \\
& \quad+2.32\left(10^{-5}\right) t^{2} \quad\left(150^{\circ} \text { to } 600^{\circ} \mathrm{C}\right) . \\
& H_{t}-H_{0}=-4.37+0.1147 t \\
& +2.31\left(10^{-5}\right) t^{2} \quad\left(600^{\circ} \text { to } 900^{\circ} \mathrm{C}\right) .
\end{aligned}
$$

Monel:

$$
H_{t}-H_{0}=0.1010 t+2.20\left(10^{-5}\right) t^{2} \quad\left(0^{\circ} \text { to } 300^{\circ} \mathrm{C}\right) \text {. }
$$

Stainless steel 34\%:

$H_{t}-H_{0}=0.12508 t+1.703\left(10^{-5}\right) t^{2}$

$-9.31 \log _{10}[(t+273.2) / 273.2] \quad\left(0^{\circ}\right.$ to $\left.900^{\circ} \mathrm{C}\right)$.

Stainless steel 446 :

$$
\begin{aligned}
H_{t}-H_{0}= & 0.10781 t+5.37\left(10^{-5}\right) t^{2} \quad\left(0^{\circ} \text { to } 500^{\circ} \mathrm{C}\right) . \\
H_{t}-H_{0}= & -6.83+0.16178 t \\
& -123,000\left(10^{-0.0078 t}\right) \quad\left(600^{\circ} \text { to } 900^{\circ} \mathrm{C}\right) .
\end{aligned}
$$

Differentiation of these equations leads to the following equations for the specific heat (in cal $\mathrm{g}^{-1}$ $\left.\operatorname{deg} \mathrm{C}^{-1}\right)$ :

$80 \mathrm{Ni}-20 \mathrm{Cr}$ :

$$
\begin{array}{ll}
C_{p}=0.1033+7.6\left(10^{-5}\right) t \quad\left(0^{\circ} \text { to } 150^{\circ} \mathrm{C}\right) . \\
C_{p}=0.1079+4.64\left(10^{-5}\right) t \quad\left(150^{\circ} \text { to } 600^{\circ} \mathrm{C}\right) . \\
C_{p}=0.1147+4.62\left(10^{-5}\right) t \quad\left(600^{\circ} \text { to } 900^{\circ} \mathrm{C}\right) .
\end{array}
$$

Monel:

$$
C_{p}=0.1010+4.40\left(10^{-5}\right) t \quad\left(0^{\circ} \text { to } 300^{\circ} \mathrm{C}\right) .
$$

Stainless steel 34\%:

$$
\begin{aligned}
& C_{p}=0.1251+3.41\left(10^{-5}\right) t \\
&-4.04 /(t+273.2) \quad\left(0^{\circ} \text { to } 900^{\circ} \mathrm{C}\right) .
\end{aligned}
$$

Stainless steel 446:

$$
\begin{aligned}
& C_{p}=0.1078+1.074\left(10^{-4}\right) t \quad\left(0^{\circ} \text { to } 500^{\circ} \mathrm{C}\right) . \\
& C_{p}=0.1618+2209\left(10^{-0.0078 t}\right) \quad\left(600^{\circ} \text { to } 900^{\circ} \mathrm{C}\right) .
\end{aligned}
$$

Specific-heat values calculated for even temperatures from eq (8 to 14) are listed in table 3.

The specific heats of the four alloys are shown graphically in figures 1 to 4 . The lines represent the smooth values given by eq ( 8 to 14), and the points correspond to the unsmoothed corrected values calculated for short temperature intervals from pairs of successive values given in table 2 .

The representation of the specific heat of $80 \mathrm{Ni}-20$ $\mathrm{Cr}$ by straight lines in figure 1 is convenient and
TABle 3. Specific heat (smoothed)

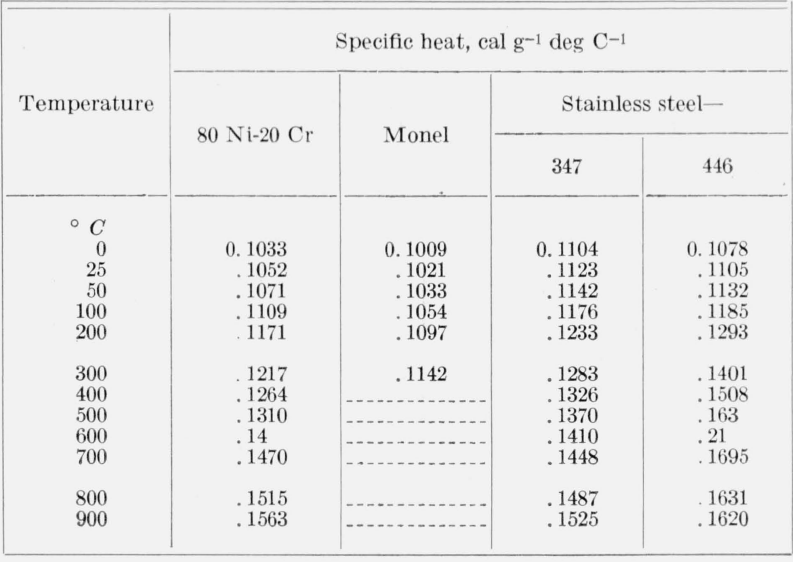

within the accuracy of the data, which however do not justify the assumption of a real discontinuity in slope at $150^{\circ} \mathrm{C}$. On the other hand, real discontinuities do appear for $80 \mathrm{Ni}-20 \mathrm{Cr}$ near $600^{\circ} \mathrm{C}$ (fig. 1) and for stainless steel 446 between $500^{\circ}$ and approximately $650^{\circ} \mathrm{C}$ (fig. 4). Although the total enthalpy changes over these regions were measured as precisely as in the other cases, the exact variation of specific heat with temperature in these regions of transition was not established because the enthalpy measurements did not cover sufficiently small temperature intervals. Otherwise the smoothed specific heats represented by eq ( 8 to 14), table 3 , and the lines in figures 1 to 4 are believed to be accurate within \pm 2 percent, at least for the actual specimens measured.

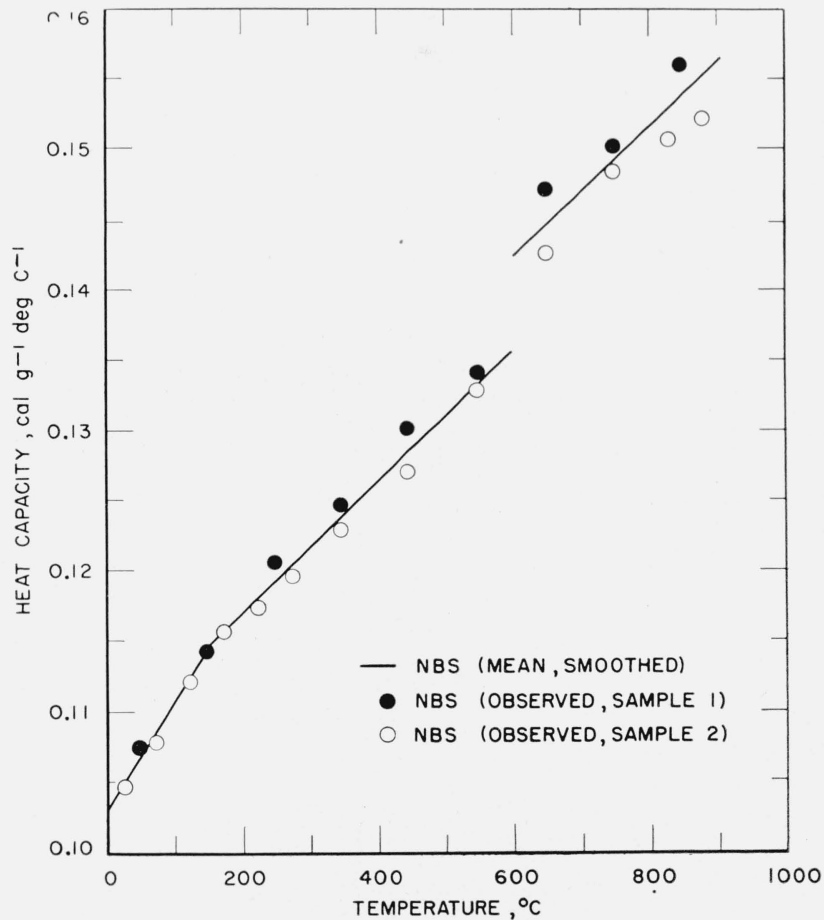

Figure 1. Specific heat of $80 \mathrm{Ni}-20 \mathrm{Cr}$. 


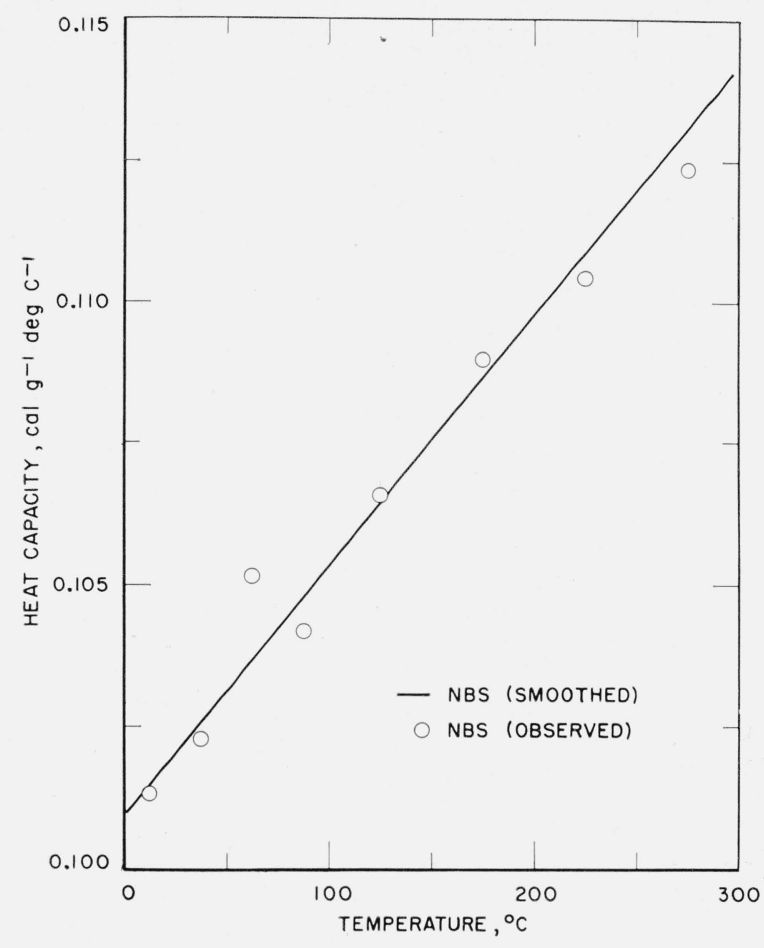

Figure 2. Specific heat of Monel.

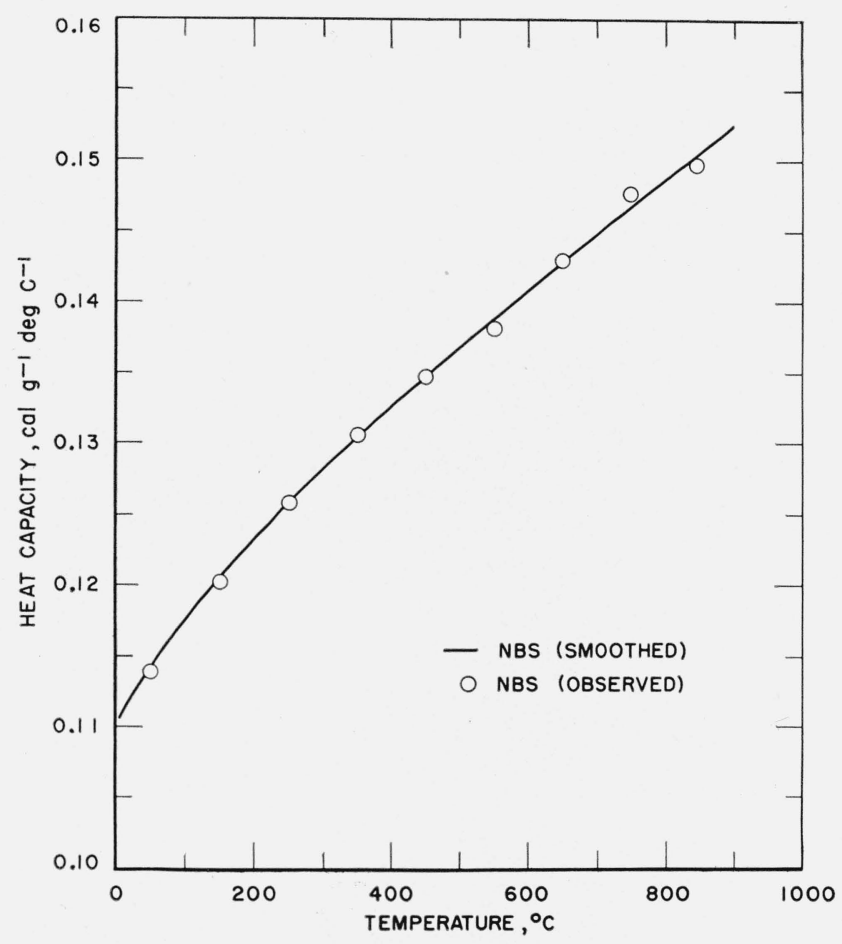

Figure 3. Specific heat of siainless steel 34\%.

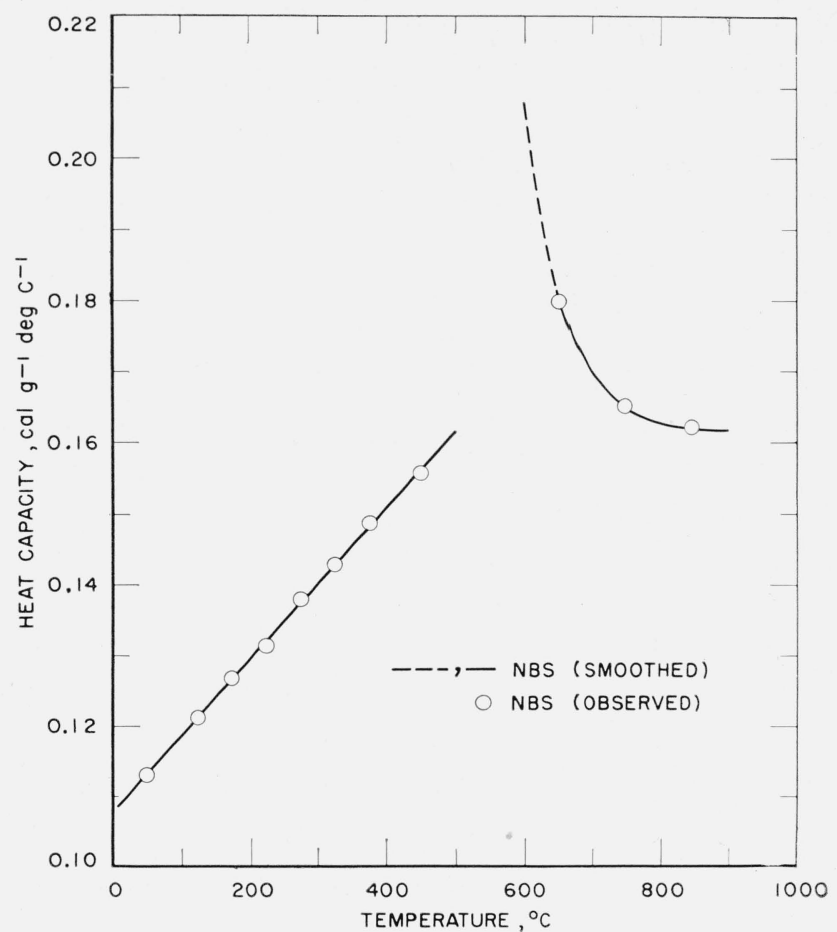

FigurE_4. Specific heat of stainless steel $4_{4} 6$.

\section{Discussion}

The following is a comparison of the specific-heat values (in cal $\mathrm{g}^{-1} \mathrm{deg} \mathrm{C}^{-1}$ ) obtained in the present work with those given in reference [3]. A value of 0.107 given for $80 \mathrm{Ni}-20 \mathrm{Cr}$ [3, p. 1060], presumably near room temperature, is the same as that given for $50^{\circ} \mathrm{C}$ in table 3 . For stainless steel 347 , the average between $0^{\circ}$ and $100^{\circ} \mathrm{C}$ is given as 0.120 [3, p. 566]; the present work gives a corresponding value 5 percent lower. For wrought stainless steel 446, 0.144 at $100^{\circ} \mathrm{C}$ is listed [3, p. 555]; the corresponding value of this paper for stainless steel 446 is about 20 percent lower. A value of 0.127 at $1,260^{\circ} \mathrm{C}$ is listed for standard Monel [3, p. 1049], but is not necessarily in disagreement with the present results, which extend up to only $300^{\circ} \mathrm{C}$. Compared with a value for Monel of 0.0997 at $20^{\circ} \mathrm{C}$, obtained with an adiabatic calorimeter [4], the present result is 2 percent higher.

A comparison of the specific heat found for stainless steel 347 with corresponding values measured at the National Physical Laboratory (London) [5] for a stainless steel of somewhat similar composition (8.14 percent of nickel, 19.11 percent of chromium, 0.37 percent of manganese, 0.68 percent of silicon, 0.08 percent of carbon, and 0.60 percent of tungsten) may be significant. The specific heats of the latter steel recorded in table 4 are the average values found for successive 50-deg intervals whose mean temperatures were those listed. The values given for stainless steel 347 were calculated from eq (12). Though the regularity in variation with temperature indicates the 
absence of a transition in the case of stainless steel 347 , the specific heat of the other steel shows, between $550^{\circ}$ and $600^{\circ} \mathrm{C}$, a small anomalous rise that is ordinarily attributed to some sort of transition.

The present investigation shows, over a temperature region above $500^{\circ} \mathrm{C}$, a very marked increase in the specific heat of the particular sample of stainless steel 446 investigated. Though the details of this transition may depend somewhat critically on the exact chemical composition of the sample, it appears that the effect observed is to be associated with the magnetic-transformation point at approximately $600^{\circ} \mathrm{C}$ that has been reported for iron-chromium alloys of this composition [6].

Several investigators have found an anomalous behavior in a number of physical properties of 80 $\mathrm{Ni}-20 \mathrm{Cr}$ in the temperature region just below and above $600^{\circ} \mathrm{C}$. An abnormal change with temperature of the thermal expansion from $500^{\circ}$ to $600^{\circ} \mathrm{C}$ was found [7], and a marked increase in the specific heat as the temperature rises above $500^{\circ} \mathrm{C}$ has been reported by others [8]. Recent measurements have been made of the specific electrical resistivity and specific heat of this alloy over the temperature range from $400^{\circ}$ to $760^{\circ} \mathrm{C}$ [9]. These measurements show, with increasing temperature, a decrease of electrical resistivity and an anomalous increase in specific heat, tentatively explained by assuming that the alloy contained regions of very-short-range order whose number or size decreases as the temperature increases. The data indicated furthermore that the specific heat was somewhat less after the alloy had been quenched from $1,000^{\circ} \mathrm{C}$ than after it had been heated at $500^{\circ} \mathrm{C}$ and then cooled slowly.

The discontinuity in the specific heat of $80 \mathrm{Ni}-20$ Cr near $600^{\circ} \mathrm{C}$ shown in figure 1 represents a behavior not encountered in most transitions. As the temperature rises, the specific heat rather abruptly shifts to a higher, parallel line. Within the accuracy of the measurements, all the heat absorbed by the alloy is represented by the area under the curves. Since a "hump" such as that often found in the specific-

TABLE 4. Specific heat of two stainless steels of similar compositions

\begin{tabular}{|c|c|c|c|}
\hline \multirow{2}{*}{ Temperature } & \multicolumn{3}{|c|}{ Specific heat, cal g-1 $\operatorname{deg} \mathrm{C}^{-1}$} \\
\hline & $\begin{array}{c}19 \% \mathrm{Cr}, 8 \% \\
\mathrm{Ni}(\mathrm{NPL})\end{array}$ & $\begin{array}{c}\text { Stainless steel } \\
347 \text { (NBS) }\end{array}$ & Difference \\
\hline $\begin{array}{r}{ }^{\circ} C \\
75 \\
125 \\
175 \\
225 \\
275\end{array}$ & $\begin{array}{r}0.122 \\
.126 \\
.127 \\
.129 \\
.131\end{array}$ & $\begin{array}{r}0.116 \\
.119 \\
.122 \\
.125 \\
.127\end{array}$ & $\begin{array}{r}0.006 \\
.007 \\
.005 \\
.004 \\
.004\end{array}$ \\
\hline $\begin{array}{l}325 \\
375 \\
425 \\
475 \\
525\end{array}$ & $\begin{array}{l}.134 \\
.136 \\
.139 \\
.142 \\
.150\end{array}$ & $\begin{array}{l}.129 \\
.132 \\
.134 \\
.136 \\
.138\end{array}$ & $\begin{array}{l}.005 \\
.004 \\
.005 \\
.006 \\
.012\end{array}$ \\
\hline $\begin{array}{l}575 \\
625 \\
675 \\
725 \\
775\end{array}$ & $\begin{array}{l}.155 \\
.151 \\
.149 \\
.150 \\
.153\end{array}$ & $\begin{array}{l}.140 \\
.142 \\
.144 \\
.146 \\
.148\end{array}$ & $\begin{array}{l}.015 \\
.009 \\
.005 \\
.004 \\
.005\end{array}$ \\
\hline $\begin{array}{l}825 \\
875\end{array}$ & $\begin{array}{l}.155 \\
.153\end{array}$ & $\begin{array}{l}.149 \\
.151\end{array}$ & $\begin{array}{l}.006 \\
.002\end{array}$ \\
\hline
\end{tabular}

heat curve of a substance in its transition region is missing, there is no heat of transition. In addition, more recent unpublished results obtained at the Bureau, which are considerably more precise than those on $80 \mathrm{Ni}-20 \mathrm{Cr}$, unmistakably show similar behavior. These recent values are for two alloys manufactured under the trade name Inconel (approximately 8 percent of iron, 76 percent of nickel, 15 percent of chromium, and 0.05 percent of carbon), in which the amounts of the two major constituents are not greatly different from the amounts in 80 $\mathrm{Ni}-20 \mathrm{Cr}$.

The behavior of these alloys may be analogous to that of cobalt. On the basis of enthalpy measurements by a number of investigators, Kelley [10] gave the heat of its transition near $400^{\circ} \mathrm{C}$ as zero. This seems plausible, because according to $\mathrm{X}$-ray analysis the transition is from a close-packed-hexagonal to a face-centered-cubic phase [11], a process that involves no change in atomic coordination number and only a slight change in the interatomic distance. It has similarly been found that the nickel-chromium alloys with less than 45 percent of chromium have a facecentered-cubic structure (presumably at room temperature) [12], and an explanation similar to that suggested for cobalt may hold in the case of 80 $\mathrm{Ni}-20 \mathrm{Cr}$.

Most of the experimental work was supported by the Atomic Energy Commission. D. C. Ginnings, Anne F. Ball, and Ann W. Harman, of the National Bureau of Standards, assisted in making a large number of the measurements. The chemical analyses of the $80 \mathrm{Ni}-20 \mathrm{Cr}$, Monel, and stainless steel 347 were performed by B. B. Bendigo, also of NBS. Stainless steel 446 and its chemical analysis were supplied by the Allegheny Ludlum Steel Corporation.

\section{References}

[1] D. C. Ginnings and R. J. Corruccini, J. Research NBS 38, 583 (1947) RP1796; 38, 593 (1947) RP1797.

[2] D. C. Ginnings, T. B. Douglas, and A. F. Ball, J. Research NBS 45, 23 (1950) RP2110.

[3] Metals Handbook, Am. Soc. Metals (Cleveland, Ohio, 1948).

[4] W. F. Hampton and J. H. Mennie, Can. J. Research 7, 677 (1932).

[5] The physical properties of a series of steels, part II, J. Iron Steel Inst. 154 (II) 83 P (1946).

[є] M. Hansen, Der Aufbau der Zweistofflegierungen, P. 522 (Julius Springer, Berlin, 1936).

[7] P. Chevenard, J. Inst. Metals 36, 39 (1926).

[8] H. Grover and J. Hutzenlaub, Phys. Rev. 56, 212 (1939).

[9] J. M. Hinkle, Microfilm Abstr. [1] 9, 150 (University Microfilms, Ann Arbor, Mich., 1949).

[10] K. K. Kelley, Contribution to the data on theoretical metallurgy. X. High-temperature heat-content, heatcapacity, and entropy data for inorganic compounds, U. S. Bur. Mines Bull. 476, 59 (U. S. Government Printing Office, Washington, D. C., 1949).

[11] S. B. Hendricks, M. E. Jefferson, and J. F. Schultz, Z. Krist. 73, 376 (1930).

[12] S. Sekito and Y. Matsunaga, Kinzoku-no-Kenkyu [6] 6, 229 (1929); J. Inst. Metals 42, 514 (1930) (ef. Chem. Abstracts 24, 3471 (1930)).

Washington, February 15, 1954. 